\title{
Migration, Trauma, PTSD: A Gender Study in Morrison's Jazz
}

\author{
Leila Tafreshi Motlagh (Corresponding Author) \\ Faculty of Modern Languages and Communication, Universiti Putra Malaysia \\ 43400 UPM, Serdang, Selangor, Malaysia \\ Email: leila.tafreshi@gmail.com \\ Wan Roselezam Wan Yahya \\ Faculty of Modern Languages and Communication, Universiti Putra Malaysia \\ 43400 UPM, Serdang, Selangor, Malaysia \\ Email: roselezam@gmail.com
}

Doi:10.7575/aiac.alls.v.5n.3p.120

Received: 06/04/2014

URL: http://dx.doi.org/10.7575/aiac.alls.v.5n.3p.120

Accepted: 15/05/2014

\begin{abstract}
Toni Morrison is an acknowledged master of trauma literature, however trauma theory and a gender response to trauma remain largely unaccounted for her migration literature, specifically Jazz (1992). In her novel, two migrant women are affected by the same trauma, a crime of passion. But they choose different reactions and coping strategies. This causes a fundamental change to their mental health. Morrison's migrant women are not only faced with migration stress factors, but also exposed to trauma. Managing migration stress factors in the receiving society and dealing with trauma within the migrant community demand appropriate coping strategies. Migration and segregation dissociate the black migrant community from the receiving society. Trauma and stigma, on the other hand, marginalize migrant women within the African-American community. Consequently, migration, segregation, trauma and stigma lead to isolation. Lack of social ties and social identity is associated with different mental health problems, including post-traumatic stress disorder (PTSD). The present study aims to identify major elements of trauma theory in Morrison's Jazz. Furthermore, this article explores the coping strategies that female characters use to deal with trauma. Although extensive studies have been carried out on Jazz, no single study exists which adequately covers the effects of migration, trauma, coping strategies on the female characters. The novelty of this paper lies in its inter-disciplinary approach to gender and mental health with reference to migration literature.
\end{abstract}

Keywords: Black Studies, Trauma Literature, Migration Literature, Mental Health, Social Identity

\section{Introduction}

The current study explores trauma theory and coping strategies in Toni Morrison's Jazz (1992). To this end, this article addresses a number of issues. First of all, trauma, PTSD and trauma theory will be defined. Second, stress factors and major coping strategies will be addressed according to Lazarus and Folkman's model. Third, the gender response to trauma will be discussed. Finally, we will focus on the relationship between migration, trauma, stigma and social identity in Jazz.

The setting of Jazz starts with a traumatic event, a crime of passion, and leads to PTSD. Jazz is not a crime and punishment story, it is about trauma in a migrant society. Two migrant women, Violet Trace and Alice Manfred, are affected differently by trauma. More importantly, these two women are at different ends of the same trauma. Subsequently, they display different reactions and coping strategies. Joe Trace kills his teenage mistress, Dorcas. His wife, Violet Trace, finds out at the funeral. After a violent reaction, she insists to meet Mrs Manfred. She was the victim's guardian after her parents were slaughtered in the East St. Louis race riot. This article critically traces trauma, coping strategies and the interaction of two traumatized women in a migrant community.

Trauma is usually defined as an unpredictable event, such as an accident or sexual assault with long-lasting consequences. Trauma is associated with feelings of horror and helplessness (Ochberg, 2000). Some psychologists believe that, "[e]xposure to trauma can be life changing" (Perera \& Frazier, 2013). The physical and/or psychological consequences of trauma may lead to PTSD (Friedman, 2000a; Mollica, 2012; Scott \& Palmer, 2000; Williams \& Poijula, 2013).

"PTSD includes episodic re-expediting of traumatic events, in the form of dysphoric memories. Because these memories are vivid, frightening and unexpected, they have secondary effects, causing sufferers to doubt their sanity, their progress in recovery, their fundamental sense of security" (Ochberg, 2000). PTSD causes horror, distress and anxiety. This leads to a sense of insecurity, but security is regarded as one of the fundamental needs of human beings (Williams \& Poijula, 2013). 
Generally, the mind cannot distinguish the notion of time. For instance, when characters have PTSD and relive trauma memories, the mind perceives these as the actual event. Therefore, the individual shows the same psychological arousal that occurred at the time of the event. In other words, the mind perceives trauma memories as trauma happening in the here and now. "With Post-Traumatic Stress Disorder people get sucked into the details of the incident like a 'black hole' that can swallow you up" (Scott \& Palmer, 2000a).

Trauma is one of the main elements and stress factors in Morrison's Jazz. However, far too little attention has been paid to trauma and coping strategies in criticism. (Beaulieu, 2004; Bloom, 2005; Dobbs, 2012; Gillespie, 2008; Kodat, 2001; Matus, 1998; Mayberry, 2000; Mbalia, 2010; Munton, 1997; Paquet-Deyris, 2001; Peach, 1998; Tally, 2007) Yet trauma scholars, like Williams and Poijula, divide trauma into pre-trauma events, trauma and post-trauma factors. Accordingly, the main event is regarded as the reference trauma. Previous exposure to trauma and/or similar events are considered pre-trauma factors that may lead to trauma patterns. In such cases, characters usually employ the same coping strategies and display similar behaviour, "[P]re-trauma factors often influence how a person reacts to traumatic events" (Williams \& Poijula, 2013). Post-trauma factors usually include methods of confronting trauma. In line with Williams and Poijula's findings, this article too focuses on pre-trauma, trauma and PTSD in traumatized women. Accordingly, trauma factors and coping strategies affect characters differently. In Jazz, the female characters who are affected by trauma respond differently.

Since almost every single character in the novel has had previous exposure to various traumas, trauma in this article refers to a crime of passion as the reference event and main incident of the novel, because the very opening paragraphs of Jazz reveal the trauma, immediate coping strategies and consequences.

\section{Theory}

In Jazz, female characters face different sources of stresses, such as migration and trauma. Psychologists believe that migration is a stressful process (Bhugra \& Jones, 2001; Bhugra, 2000, 2001, 2003, 2004; Martin, 2004; McLeman \& Hunter, 2010; Silove et. al, 1997) Similarly, trauma is a great source of distress and anxiety and requires appropriate coping strategies (Scott \& Palmer, 2000). In Jazz, traumatized migrant women are subject to different physical and emotional stress factors, which require effective coping strategies. Otherwise, the characters will suffer unduly to various degrees.

This present study is a textual analysis of Morrison's Jazz, with reference to Lazarus and Folkman's model of coping strategies. According to their model, individuals commonly respond to trauma and its stress factors in three ways. Subsequently, it becomes evident how traumatized migrant characters respond to trauma.

The first and most effective one is problem-focused coping (Lazarus \& Folkman, 19840). As the name suggests, problem-focused coping, as an adaptive coping strategy, employs certain strategies to solve a problem or remove the source of stress, "problem-focused coping appeared to reduce depressive symptoms" (van Berkel, 2009). The second strategy, widely employed by individuals, is called emotion-focused coping, which has two functions. It manages and/or reduces the emotions associated with stressors and situations (Carver et al., 1989); "Seeking social support for instrumental reasons is getting moral support, sympathy, or understanding [...] That is, a person who is made insecure by a stressful transaction can be reassured by obtaining this sort of support" (Carver, Scheier, \& Weintraub, 1989). As aforementioned, security is a crucial factor for traumatized characters. The third coping strategy is an avoidant one. This is also known as a maladaptive defence mechanism. In comparison to so-called approach strategies, problem-focused and emotion-focused coping strategies, an avoidant coping strategy reduces anxiety in the short term, but the source of stress remains in the long run (Roth \& Cohen, 1986). For the purposes of this article, Lazarus \& Folkman's coping strategies are referred to when considering Morrison's Jazz. Notably, traumatized women employ different coping strategies to approach or avoid trauma.

If individuals fail to consider appropriate coping strategies, they may go through trauma therapy. Matthew F. Friedman classifies three phases of trauma therapy, including: first, building trust to lower one's traumatic guard; second, exploring traumatic recollections; and finally helping the traumatized person to detach from the trauma and reattach to family and society (Friedman, 2000a).

Accordingly, this paper considers that a confrontation between traumatized women is a trauma therapy session. Violet Trace starts to visit Alice Manfred on a regular basis. Actually, the former insists on visiting and the latter initially refuses. Textual investigation indicates that Mrs Manfred employs an avoidant coping strategy, while Violet Trace uses an emotion-focused coping strategy. Despite all their trauma-related emotions, Violet Trace and Alice Manfred meet each other and establish mutual trust. Based on Friedman's theory, the two traumatized women lower their guard. Then, they review trauma-related memories. At the end of the day, they are a little bite detached from the trauma; however, they are also not attached to society.

As far as trauma is concerned, one of the main problems regarding Toni Morrison's criticism can be identified as inadequate and unsystematic methods to address trauma. In the case of Morrison's Jazz, most literary criticism has only been conducted in small areas of migration and trauma (Dobbs \& Grewal, 1998; Matus, 1998; Paquet-Deyris, 2001). In spite of all the efforts, some criticism does not address precise trauma and stress factors or appropriate coping strategies. Therefore, this article attempts to conduct a systematic analysis of trauma and coping strategies with reference to gender, trauma and migration literature. 


\section{Discussion}

In Jazz, it becomes increasingly difficult to ignore the strategies for coping with trauma. The first few pages of Jazz illustrate different reactions and coping strategies. Approaching or avoiding trauma makes a fundamental difference to one's mental health and well-being (Carver et al., 1989; Chen \& Bargh, 1999; Roth \& Cohen, 1986). Notably, the gender response to trauma plays a significant role. The two women, Violet Trace and Alice Manfred, are affected by trauma. The former approaches the trauma and the latter avoids it. This paper attempts to examine step-by-step coping strategies relating to trauma.

In Jazz, trauma refers to a crime of passion. Trauma and coping strategies appear in the opening paragraphs of the novel. Indeed, the first few pages of the novel can be interpreted as immediate coping strategies. Joe and Violet Trace migrated from the South to New York during the Great Migration, or as part of black migration. They live in an African-American migrant community. Joe Trace, a middle-aged husband, shoots his eighteen-year-old black mistress, Dorcas. His wife, Violet Trace, finds out at the funeral. Violet's immediate coping strategy to deal with this traumatic event is a violent reaction. She attacks the corpse with a knife during the ceremony and is thrown out of the church. This psychological reaction to trauma is considered an emotion-focused coping strategy.

Friedman states that psychological arousal, like a startled reaction, may occur during or after trauma (Friedman, 2000b). Nonetheless, the extent of her reaction is questionable. After this unsuccessful attempt, Violet tries different coping strategies throughout the story. Unfortunately, existing accounts of violence and anger fail to resolve the reference trauma and this leads to further trauma and PTSD. As a consequence, the African-American community ostracizes Violet and gives her the name Violent. Meanwhile, the Salem Women's Club refuses to help Violet and leaves her "to figure out on her own what the matter was and how to fix it"(Morrison, 2005).

Social ties play a beneficial role in mental health (Kawachi \& Berkman, 2001). Social ties act as a buffer for stress. After the trauma, Violet, as an African-American migrant woman, finds herself detached from the family circle, rejected by the migrant community and stigmatized by the gender club. Violet had previous exposure to trauma and subsequent loneliness and lack of support. Her father had abandoned the family, leaving them in extreme poverty. And her mother had committed suicide. Thus, it can be inferred that she was familiar with the negative effects of trauma and lack of social attachment. Psychological research proves that, "[1]ack of attachments is linked to a variety of ill effects on health, adjustment and well-being [...] the need to belong is powerful, fundamental and extremely pervasive motivation" (Baumeister \& Leary, 1995). Consequently, Violet, as a lonely traumatized migrant woman, is more likely to succumb to all sorts of mental health problems, such as PTSD.

African-Americans, already stigmatized in the receiving society as an ethnic minority, are not willing to accept further stigma, such as a crime of passion or murder, within the migrant community. "Stigma directly affects [the] stigmatized via mechanisms of discrimination, expectancy confirmation, and automatic stereotype activation, and indirectly via threats to personal and social identity" (Major \& O'Brien, 2005). In the same way, the stigma of a crime of passion affects the social identity of the African-American migrant community as well as individual characters.

The situation becomes more stressful when the host or receiving society marginalizes migrants (Berry, 2001). The segregation of African-Americans was a widespread phenomenon during the Great Migration or black migration (Tolnay, 2003). Marginalization and segregation create minorities. A crime of passion creates stigma. Indeed, minorities do not want migration to be made more stressful by stigma (Major \& O'Brien, 2005). Therefore, the African-American migrant community rejects the couple, Joe and Violet Trace, or anyone else associated with the trauma. And losing social ties means losing buffers for different stresses.

In Jazz, two migrant women, Violet Trace and Alice Manfred, are affected by trauma, a crime of passion. Both are already under considerable stress from pre-migration, migration and post-migration stress factors. They are marginalized by the host or receiving community and also stigmatized by the African-American migrant community. Another angle on this debate sees these two women as being at different ends of the same trauma, but in the same unpleasant situation; however, the situation is even worse for Mrs Manfred. Dorcas was her only companion but Violet's husband killed her. The trauma causes the female characters to interact with each other and employ different coping strategies. Each coping strategy affects their mental health differently.

Throughout the novel, Violet Trace shows a range of emotion-focused strategies, such as outbursts of anger, love, hate, revenge and sympathy, whereas Alice Manfred actively employs any avoiding coping strategies to escape trauma and its triggers. It is worth mentioning that neither coping strategies is very effective, despite the fact that an avoiding coping strategy is more likely to lead to developing PTSD (Friedman, 2000b; Williams \& Poijula, 2013).

After the outbursts of anger and violence in church, Violet tries a number of other emotion-focused coping strategies, which are also not effective. Her second coping strategy, immediately after the funeral, was to take birds out of their cage "and set them out the windows to fly or freeze, including the parrot that said, 'I love you"' (Morrison, 2005). Her third coping strategy to deal with the crime of passion and subsequent trauma was choosing another partner, "[S]he could punish Joe by getting herself a boyfriend and letting him to visit in her own house"(Morrison, 2005). Violet's fourth coping strategy was to shift her focus to her husband's needs and emotions. But this does not resolve the problem and the source of stress remains, "Violet's next plan - to fall back in love with her husband"(Morrison, 2005).

Notably, Violet does not differentiate between various emotion-focused reactions. Another major source of uncertainty over this strategy is the mixture of her conflicting and negative emotions towards her husband as the trauma perpetrator. Monica Lanyado, trauma scholar, implies that conflicting feelings may occur after trauma (Lanyado, 2004). 
When emotion-focused strategies fail to achieve the proper response, Violet tries other coping strategies, "So she commenced to gather the rest of [the] information. Maybe she thought she could solve the mystery of love that way"(Morrison, 2005). In line with Miller's (Miller, 1987), research Carver et al. (Carver et al., 1989) found that seeking information might be helpful in dealing with stressful situations. Violet gathers all the necessary information and details about the crime of passion and the victim, Dorcas, including her appearance, lip rouge, hairstyle, favourite band, dance steps, the love nest, her school, the teachers, her address, her photo and her parents' deaths in the East St. Louis riot. To this end, Violet meets Dorcas' guardian, Mrs Manfred.

Finally, Violet decides to meet Mrs Manfred. Based on Matthew Friedman's trauma therapy mentioned earlier, the meeting of the two women is considered a trauma therapy. The confrontation between these two women affected by trauma is a critical moment. The situation is even worse for Alice Manfred, because she was witness to the trauma when Violet slashed Dorcas' face at the funeral. Mrs Manfred believes that a "man had come in her living room and destroyed her niece. His wife had come right in the funeral to nasty and dishonor her"(Morrison, 2005). Violet becomes a trauma trigger for Mrs Manfred, so she consistently employs an avoidant coping strategy to avoid Violet, a trauma trigger. Psychologists believe that dealing with trauma triggers plays an important role in PTSD (Scott \& Palmer, 2000). Violet Trace and Alice Manfred become constant reminders of trauma for each other.

Jazz explains the psychological state of Mrs Manfred after the trauma, "Idle and withdrawn in her grief and shame, she whittled away the days making lace of nothing... "(Morrison, 2005). Idleness, numbness, the recollection of traumatic events and exposure to anger, grief and shame, are generally recognised as PTSD symptoms (Kodat, 2001; Schweitzer et al., 2006; Scott, 2000; Williams \& Poijula, 2013). Numbness, recollections of memories and trauma flashbacks interrupt daily activities, because they decrease characters' productivity and hamper their ability to cope. Scott's highlights that, in the months following trauma, most traumatized people are detached from daily life (Scott, 2000).

Alice Manfred regularly finds herself interrupted by trauma flashbacks. "Toward the end of March, Alice Manfred put her needles aside to think again of what she called the impunity of a man who killed her niece just because he could"(Morrison, 2005). Mrs Manfred consciously tries either to block out or eliminate memories related to trauma, but the memories keep coming back. Blocking out trauma flashbacks is an avoiding coping mechanism that represents the negative emotions associated with trauma (Williams \& Poijula, 2013). Scott states that blocking memories does not help traumatized people because the memories will come back in different ways. Instead, it is better to take charge of memories rather than being controlled by them (Scott, 2000).

It is important to highlight that safety is a fundamental psychological need for the individual and a critical issue for survivors of and witnesses to trauma (Williams \& Poijula, 2013), "Recently she [Mrs Manfred] had begun to feel safe nowhere... "(Morrison, 2005). Jazz presents different accounts of trauma associated with feeling or being unsafe. For instance, she " ...feels truly unsafe because brutalized men and their brutal women were not out there but they were in her block, her house" (Morrison, 2005). Mrs Manfred, who had previous exposure to trauma in the East St. Louis race riot, has safety concerns. To this end, she admits that not only whites but also blacks can be dangerous, "More than unappealing, they were dangerous" (Morrison, 2005). Despite these safety concerns, some of these feelings, such as the anger, self-blame and guilt that emerge from defence mechanisms, are trauma-related symptoms (Scott \& Palmer, 2000b; Williams \& Poijula, 2013). Mrs Manfred is lonely and detached from daily life. Her trauma patterns indicate that she actively employs an avoidant coping strategy and is thus more likely to develop PTSD.

This article considers the visits of the two traumatized women to be trauma therapy sessions. Violet Trace's several visits to Alice Manfred's house can be interpreted as therapy sessions for both the traumatized migrant women. According to Friedman's model, both women pass through three stages of trauma treatment. First, they lower their traumatic guard. Then, they establish mutual trust. Finally, they detach from the reference trauma to some extent, though they are not attached to the migrant community or receiving society. At first, Alice Manfred keeps up her traumatic guard and wants to call the police. As the women find they are almost the same age, barren, betrayed, lonely and self-made migrants, they build mutual trust. After overcoming trauma memories, it seems that they are slightly detached from the reference trauma; however, Jazz gives no account of their being attached to the migrant community or receiving society. Consequently, it can be inferred that these meetings are a kind of trauma therapy for both women.

Jazz starts in winter and ends in spring. The novel starts in early January, and the so-called meetings of the two traumatized women continue in the two following months. Then, Jazz no longer gives the psychological account of two traumatized women. As the novel ends, we find the female characters are in a better psychological condition than at the beginning of the novel, immediately after the trauma. It can be inferred that the trauma is now less painful, at least on a personal level; however, the traumatized characters have a long way to go in the community and receiving society.

In this article, we have highlighted the personal and social aspects of trauma in a migrant society. As far as the personal dimensions of trauma are concerned, the female characters overcome certain emotions which are associated with trauma and PTSD. On the other hand, the African-American migrant community is not yet ready to accept the stigmatized members. As a result, the traumatized characters remain isolated, in both the community and the host society. These findings imply that loneliness and a lack of personal and social bonds again lead to distress and mental health problems (Baumeister \& Leary, 1995; Hornsey \& Jetten, 2004). 


\section{Conclusion}

This article has addressed a number of significant issues which show how female characters respond to trauma. In Jazz, we have one trauma, two women and two different coping strategies. One of them actively employs an avoidant coping strategy. The other employs an emotion-focused strategy. The outcomes of the strategies and the interaction of the two traumatized women are highlighted according to trauma theory in the novel. Based on Matthew Friedman's trauma treatment model, the confrontation of the two traumatized women helps them to detach from the trauma, though they are not attached to social life. Likewise, the social identity of a migrant society and ethnic minorities is affected by trauma

Migration is a stressful process that mainly marginalizes characters in the host or receiving society. The trauma, a crime of passion, stigmatizes the characters, even within a migrant community. Maladapted coping strategies, detachment from the migrant community and the receiving society lead to loneliness. Consequently, migration, trauma, stigma and loneliness make the female characters more vulnerable to mental health problems, such as PTSD. Lack of social support and social identity make their psychological state even more critical.

\section{References}

Baumeister, R. F., \& Leary, M. R. (1995). The Need to Belong: Desire for Interpersonal Attachments as a Fundamental Human Motivation. Psychological Bulletin, 117(3), 497-529. Retrieved from http://www.ncbi.nlm.nih.gov/pubmed/7777651

Beaulieu, E. A. (Ed.). (2004). The Toni Morrison Encyclopedia. African American Review (Vol. 38, p. 168). Connecticut: Greenwood Press. doi:10.2307/1512248

Berry, J. W. (2001). A Psychology of Immigration. Journal of Social Issues, 57(3), 615-631. doi:10.1111/00224537.00231

Bhugra, D. (2000). Migration and Schizophrenia. Acta psychiatrica Scandinavica. Supplementum, 102(407), 68-73. Retrieved from http://www.ncbi.nlm.nih.gov/pubmed/11261645

Bhugra, D. (2001). African-Caribbeans and Schizophrenia: Contributing Factors. Advances in Psychiatric Treatment, 7(4), 283-291. doi:10.1192/apt.7.4.283

Bhugra, D. (2003). Migration and Depression. Acta psychiatrica Scandinavica. Supplementum, 108(418), 67-72. Retrieved from http:/www.ncbi.nlm.nih.gov/pubmed/12956818

Bhugra, D. (2004). Depression in Migrants and Ethnic Minorities. Advances in Psychiatric Treatment, $10(1), 13-17$. doi:10.1192/apt.10.1.13

Bhugra, D., \& Jones, P. (2001). Migration and Mental Illness. Advances in Psychiatric Treatment, 7, $216-223$. Retrieved from http://www.ncbi.nlm.nih.gov/pubmed/7371420

Bloom, H. (2005). Bloom's Modern Critical Views Toni Morrison (p. 232). Philadelphia: Chelsea House.

Carver, C. S., Scheier, M. F., \& Weintraub, J. K. (1989). Assessing Coping Strategies: A Theoretically Based Approach. Journal of personality and social psychology, 56(2), 267-83. Retrieved from http://www.ncbi.nlm.nih.gov/pubmed/2926629

Chen, M., \& Bargh, J. A. (1999). Consequences of Automatic Evaluation: Immediate Behavioral Predispositions to Approach or Avoid the Stimulus. Personality \& social psychology bulletin, 25(2), 215-224.

Dobbs, C. (2012). Toni Morrison (Review). Collage Literature, 39(4), 148-149. Retrieved from http://muse.jhu.edu

Dobbs, C., \& Grewal, G. (1998). Circles of Sorrow, Lines of Struggle: The Novels of Toni Morrison. African American Review (Vol. 34, p. 362). Lousiana State University Press. doi:10.2307/2901266

Friedman, M. J. (2000a). PTSD Diagnosis and Treatment for Mental Health Clinicians. In M. J. Scott \& S. Palmer (Eds.), Trauma and Post-traumatic Stress Disorder (p. 153). London: Cassell.

Friedman, M. J. (2000b). Post-Traumatic Stress Disorder: The Latest Assessmant and Treatment Strategies (p. 108). Kansas City: MO: Compact Clinicals.

Gillespie, C. (2008). Critical Companion to Toni Morrison: A Literary Refrence to Her Life and Work (p. 497). New York: Facts On File.

Hornsey, M. J., \& Jetten, J. (2004). The individual Within the Group Balancing the Need to Belong With the Need to be Diffrent. Personality and Social Psychology Review, 8(3), 248-264. doi:10.1207/s15327957pspr0803

Kawachi, I., \& Berkman, L. F. (2001). Social Ties and Mental Health. Journal of Urban Health: Bulletin of the New York Academy of Medicine, 78(3), 458-67. doi:10.1093/jurban/78.3.458

Kodat, C. G. (2001). Quiet As It's Kept: Shame, Trauma, and Race in the Novels of Toni Morrison (review). MFS Modern Fiction Studies, 47(4), 1033-1035. doi:10.1353/mfs.2001.0090

Lanyado, M. (2004). The Presence of the Therapist (p. 158). New York: Burnner-Routledge.

Major, B., \& O’Brien, L. T. (2005). The Social Psychology of Stigma. Annual review of psychology, 56, $393-421$. doi:10.1146/annurev.psych.56.091103.070137 
Martin, S. F. (2004). Women and Migration. In S. Forbes Martin (Ed.), Migration and Mobility and How This Movement Affects Women (Vol. CM/MMW/200, pp. 1-35). Malmo, Sweden: United Nations Division for the Advancement of Women (DAW).

Matus, J. (1998). “A Sweettooth for Pain”: History, Trauma and Replay in Jazz. In Toni Morrison, Contempoary World Writers (pp. 121-144). Manchester: Manchester Univeristy Press.

Mayberry, K. J. (2000). The Problems of Narrative in Toni Morrison's Jazz. In Toni Morrison's Fiction: Contemporary Criticism (pp. 297-309). New York: Garland Publishing, Inc.

Mbalia, D. D. (2010). TONI MORRISON'S: Developing Class Consciousness, Second Edition (2nd ed.).

McLeman, R. a, \& Hunter, L. M. (2010). Migration in the context of vulnerability and adaptation to climate change: insights from analogues. Wiley interdisciplinary reviews. Climate change, 1(3), 450-461. doi:10.1002/wcc.51

Miller, S. M. (1987). Monitoring and Blunting: Validation of a Questionar to Access Style of Information Seeking Under Treat. Journal of Personality and Social Psychology, 52, 345-353.

Mollica F, R. (2012). Textbook of Global Mental Health: Trauma and Recovery, A Companion Guide for Field and Clinical Care of Traumatized People Worldwide. (R. Mollica F, Ed.) (Harvard Pr., p. 559). Harvard.

Morrison, T. (2005). Jazz (p. 230). London: Vintage.

Munton, A. (1997). Misreading Morrison, Mishearing Jazz: A Response to Toni Morrison's Jazz Critics. Journal of Amercian Studies, 31(02), 235-251. Retrieved from http://journals.cambridge.org/abstract_S0021875897005653

Ochberg, F. M. (2000). The Counting Method Ameliorating Trauamtic Memories. In M. J. Scott \& S. Palmer (Eds.), Trauma and Post-traumatic Stress Disorder (pp. 122-136). New York: Cassell.

Paquet-Deyris, A.-M. (2001). Toni Morrison's Jazz and the City. African American Review, 35(2), $219-231$.

Peach, L. (Ed.). (1998). New Casebooks Toni Morrison (p. 2011). London: Macmillan Press LTD.

Roth, S., \& Cohen, L. J. (1986). Approach, Avoidance, and Coping With Stress. The American Psychologist, 41(7), 813-9. Retrieved from http://www.ncbi.nlm.nih.gov/pubmed/3740641

Scott, M. J., \& Palmer, S. (2000). Trauma and Post-Traumatic Stress Disorder. London: Cassell.

Silove, D., Sinnerbrink, L., Field, A., Manicavasagar, V., \& Steel, Z. (1997). Anxiety, Depression and PTSD in Asylum-Sseekers: Assocations with Pre-migration Trauma and Post-Migration Stressors. The British Journal of Psychiatry, 170, 351-357. doi:10.1192/bjp.170.4.351

Tally, J. (2007). The Cambridge Companion to Toni Morrison (p. 208). Cambridge: Cambridge.

Tolnay, S. E. (2003). The African American "Great Migration” and Beyond. Annual Review of Sociology, 29(1), 209232. doi:10.1146/annurev.soc.29.010202.100009

Williams, M. B., \& Poijula, S. (2013). The PTSD Workbook (Second., p. 362). Oakland: New Harbinger Publications Inc. 